\title{
PRESS JOURNALIST'S PROFESSION IN POLAND AFTER POLITICAL TRANSFORMATION IN 1989 AND NOWADAYS
}

\author{
Joanna Mikosz*
}

\begin{abstract}
The article presents press journalist's profession in Poland after the political transformation in 1989 and nowadays. In the first part the Author discusses changes in press journalism occupation after the political transformation in Poland in 1989. Joanna Mikosz presents the work conditions in Polish editorial offices and consequences of appearing foreign publishing houses at the Polish press market. The article shows positive and negatives changes of transformation in the shape of Polish newspapers and magazines and work of journalist's profession. The last part of the considerations will attempt of answer what kind of role press journalism in Poland plays nowadays, what kind of dailies and magazines are the most popular and in which direction will go in their development.
\end{abstract}

Key words: journalist's profession, journalist's profession in Poland, political transformation in Poland

\section{Introduction}

Journalism is the activity of gathering, assessing, creating, and presenting news and information. It is also the product of these activities (Słownik terminologii medialnej, 2006, p. 43). Journalism can be distinguished from other activities and products by certain identifiable characteristics and practices. These elements not only separate journalism from other forms of communication, they are what make it indispensable to democratic societies. History reveals that the more the democratic society, the more news and information it tends to have. As Marek Chyliński and Stephan Russ-Mohl state: "Full freedom of journalism is only in seven countries in the world. On the top of the each year list of "World Freedom Index" published by the organisation "Reporters Without Borders"***

\footnotetext{
* PhD at the Department of Journalism and Social Communication, Lodz University, Poland, e-mail: mikoszj@wp.pl

** Reporters Without Borders (RWB), or Reporters Sans Frontières (RSF), is an international non-profit, non governmental organization that promotes and defends freedom of information and freedom of press. The organization, with a head office in Paris, France, has a consultant status at the United Nations. Reporters Without Borders has two primary spheres of activity: one is focused on Internet censorship and the new media, and the other on providing material, financial and psychological assistance to journalists assigned to dangerous areas. Its missions are to: continuously monitor attacks on freedom of information worldwide; denounce any such attacks in the media; act in cooperation with governments
} 
are: Denmark, Finland, Iceland, Ireland, Netherlands, Norway and Switzerland (Chyliński, Mohl, 2008, pp.14-19).

Changes that took place in 1989 had a great meaning for Poland, especially for the subsequent political and economic transformations. The introduction of the democratic system, the transition from the state-controlled economy to the free market one, and undertaking sweeping reforms were the driving force behind the new Polish economy. Political transformation had some influence on the face of Polish journalism too. Poland was the first country from the communist block which entered the path of transformation.

\section{Previous research in the field}

There are a lot articles and books which discuss the problem of the political transformation in Poland in 1989 and its influences on journalist' s occupation. The study at hand is a continuation in the wide array of research conducted at Polish universities. Results of them were also presented at many academic conferences.

A very profound study was conducted by Z. Bajka (Dziennikarze lat dziewięćdziesiątych, R. Filas (Dziesięć lat przemian mediów masowych w Polsce (1989-1990), 1999), K. Pokorna - Ignatowicz (Problemy zawodowe polskich dziennikarzy u progu XXI wieku, 2010), Z. Oniszczuk Z., (Strefy wpływu kapitału niemieckiego w polskich mediach, 2010).

Worth mentioning are also: I. Fiut (Pisma społeczno-kulturalne w latach 19892000, 2000), W. Pisarek (Kwalifikacje dziennikarzy w opinii redaktorów naczelnych, 1995).

It needs to be highlighted that the Polish media after 1989 got laws regulatingthe public and private media, investigative journalism, media ethics, journalists' organizations, advertising and the media, the problem of competition in the media, political lobbying and independence of the media. The binding documents concerning journalist ethics are "The Journalist's Social Code of the Association of Journalists of the Republic of Poland" passed in 1992 and "The Journalist's Social Code" as of 1948, applied to the members of the Association of Polish Journalists. Besides, in 1995 all journalism associations as well as some organizations of broadcasters accepted the charter of media ethics, where the following rules were formulated:

- the rule of truthfulness - all information must be true,

- the rule of objectivity - the author must show the reality regardless of

to fight censorship and laws aimed at restricting freedom of information; morally and financially assist persecuted journalists, as well as their families; and offer material assistance to war correspondents in order to enhance their safety. Retrieved from http://www.rog.at/ wp-content/uploads/2016/09/2016-Ausschreibung-Polnisch.pdf (2018, April 6). 
personal opinions,

- unequivocal separation between news and comments - so that the reader could distinguish between facts and comments,

- the rule of honesty - a journalist is obliged to work according to the dictates of his/her conscience,

- impartiality,

- respect, tolerance - respect for dignity, rights, personal goods, the right to privacy as well as good name of other people,

- the rule of freedom and accountability for message content, priority of the readers' rights (Sobczak, 2000, p. 196).

The objective of the journalist's work is, as was mentioned above, to serve the whole society as well as, small societies at the regional and local level and ethnic minorities. Obtaining the status of the professional journalist is "also to give to the journalist the privileged position in getting information, transparency in public life, controlling and social criticism" (Taczkowska, 2012, p.74). A journalist can frequently have dilemmas which party he/she should support and who is right. However, the recipe is simple. The journalist's duty is, first of all, to present arguments in an objective way. They can, however, reveal whose opinion seems to be more convincing. What is important, it is necessary to retain objectivity regardless of changing political powers, successive governments or prevailing ideology.

While pursuing professional assignments a journalist must be convinced that first of all he/she serves the society and their country and thus should behave according to professional ethics. A journalist is also accountable for the reception of his or her messages, so in pursuit of media success, he or she must not drive people into the trap of their inner emotions.

The press, as well as the other media, should use the truth in the service of humanity, with the purpose of development, shaping and improvement of the condition of every person. Thus, the accountability for the truth rests with individual journalists providing news.

It is important to mention the Polish Journalist' s Association (SDP). It is the oldest organization of journalists in Poland (it was established in 1951) which enjoys the greatest authority. The Association actively participates in initiatives aimed to develop a state of law and civic society. Pursuant to the provisions of its statutes, the Association is a non-profit voluntary, professional and creative association of journalists. Currently, it has 2,700 members. It has 16 local branches in the biggest towns and cities of Poland. SDP groups operate in the 
press, the radio, television and Internet editorial offices as well as information agencies*. The aims of SDP are:

- ensuring reliable media information to the society,

- supporting creative journalism,

- ensuring ethical behaviour among journalists, and

- protecting the rights of journalists.

Activities of the Association take various forms, including: conferences and seminars, discussions, contests for journalists, contacts with foreign organizations (SDP is a member of the International Federation of Journalists in Brussels).

The Polish Journalist' $\mathrm{s}$ Association takes particular care to ensure that journalists comply with the ethical rules and standards. It is also engaged in publishing activities-on its own, or in cooperation with other organizations.

\section{Methods}

In the present paper the author analysed the political and social consequences in the press market that followed in Poland after the transformation in 1989. The objective of the interest was provoked by the changes in the contents and graphics formula of dailies and magazines. The author undertook the task by showing positive and negative consequences in the profession of press journalists and how the profession is received today. The text also presented the results of researches connected with journalists' attitude to their work and results of popularity of the Polish press.

Among the methods and research techniques used during writing the article is the historical method which gives chronological and thematic ordering of the press, embedding analysis of its activity and determination of status in specific historical circumstances and accompanying social, political and economic conditions.

\section{Data Analysis}

The changes in Poland after the political transformation included the collapse of communism and opening the borders with Western European countries. New legal regulations concerning the publishing of press were passed in 1990 and they included: the abolishment of censorship and liquidation of the Central Office for the Control of Press, Publications and Cultural Events. The previous licencebased press system was transformed into the registration-based one and thus the only condition for the publishing of a newspaper became the court registration of the title, which accelerated the establishment of new papers whose existence

\footnotetext{
* Retrieved from http://old.sdp.pl/about-us (2018, August 6).
} 
depended on the market only. Besides, under a parliamentary resolution, the communist concern RSW "Prasa-Książka-Ruch" was dissolved which meant the end of state monopoly in the field of distribution and, consequently, all the papers published by RSW were sold to companies owned by Polish and foreign publishing houses. In 1992, the Law of Broadcasting was stated*. Subsequently, other laws adjusting Polish law to European Union law were enacted. In 1997 the new Polish Constitution was introduced. According to it, the freedom of the press and other media in Poland is guaranteed. Censorship and licensing of the press was prohibited, yet licensing of broadcasting was accepted. Press titles must be registered only in court.

Political transformation brought a lot of new rules in the press market. We can point out the following changes:

- polish press, from the first time since 1945 , was able to fully develop and express different points of views and opinions as well as provide the information that before was left unspoken (such as social protests);

- previous "underground" papers (like for example: Roman-Catholic Church press) as well as the papers published abroad began to be published officially (for example: "Kultura"**);

- Poland also started to be an attractive investment destination for foreign companies from many countries like: France, Germany, Italy or Scandinavia. We can indicate for example such companies as : Orkla Media, Passauer Neue Press or Jurg Marquard;

- in Poland there appeared the Polish press company too like Agora, which was established in 1989 by Andrzej Wajda, Aleksander Paszyński and Zbigniew Bujak;

- the number of newspapers and magazines has increased by almost half, from 3,007 in 1990, to 4,340 in 1995. By 2001, there were already 5,837 press titles - nationwide and local ones (as stated before, today there are more than 7000 titles) (Filas, 1999);

- in the press market there appeared new newspapers - one of the most important was "Gazeta Wyborcza"***-the first totally independent newspaper in postcommunist Poland" (Oniszczuk, 2010, p. 197);

- the cultural changes led to the rise of commercial mass press (for

\footnotetext{
* Broadcasting Act made possible the launch of private, commercial radio and television stations.

** "Kultura" - was a leading Polish-émigré literary-political magazine, published from 1947 to 2000 by Instytut Literacki (the Literary Institute), initially in Rome, then Paris. It was edited and produced by Jerzy Giedroyc and ceased publication upon his death.

*** Today, "Gazeta Wyborcza" is the main press title of Agora and one of the biggest Polish newspapers, which achieved big marketing success after 1989.
} 
example: "Super Express") based on tabloids, and sensational and erotic magazines addressed to the reader expecting rather unrefined entertainment;

- transformation also led to the vulgarization of the media and brutalization of the language (the weekly "Nie" published by Jerzy Urban);

- political changes after 1989 brought also changes of situation of social - cultural magazines in Poland. Titles connected with the previous system, no longer exist; there appeared many new titles (most of them influenced by the to process of commercialization). In this group we can distinguish film, theatre, art, photography and music magazines like: "Machina", "Film", "Wiadomości Kulturalne" or "Notatnik Teatralny" (Fiut, 2000,pp. 64-66);

- on the other hand, elegantly illustrated magazines were published (for example: "Twój Styl" - magazine for women), addressed to wealthier people;

- magazines for young people which were edited before 1989 ("Płomyk") began lose popularity. Their place took colourful magazines edited abroad like "Popcorn" or "Dziewczyna" which did not have any educational and didactic value;

- besides, there appeared a number of magazines connected with new parties and political groups, for example: "Gazeta Polska" (centre-right circles). The catholic press such as "Niedziela" (Częstochowa), "Gość Niedzielny" (Katowice) also won substantial readership;

- $\quad$ specialized titles like "Komputer Świat", "Dom i Wnętrze", "Magazyn Budowlany" also started to be printed: (Fiut ,2000, p. 66);

- the abolishment of state monopoly along with the privatization after 1989 led to the creation of a politically diversified press market. The law of supply and demand began to work there, which resulted in competitiveness. This, in turn, made the publishers adapt to the tastes and expectations of the readers. The content and graphic formula of papers got more attractive as well. The computerization of editorial offices after 1990 led to new technologies and made possible the editing newspapers and magazines in accordance with the highest European standards; 


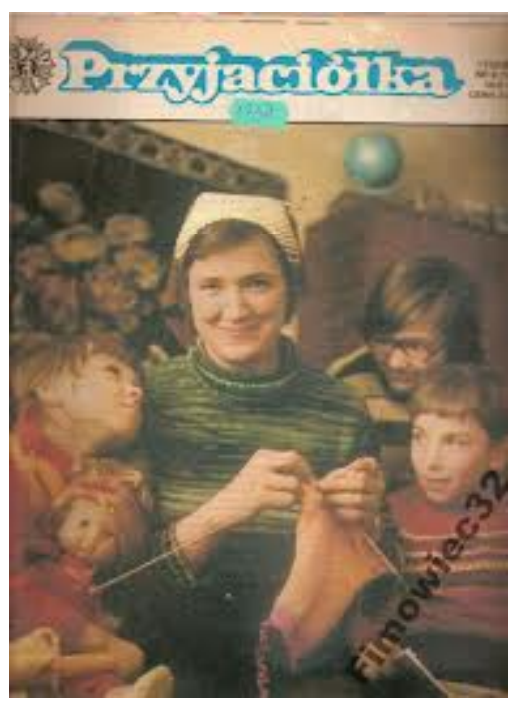

The layout of "Przyjaciótka" (magazine for women) before political the transformation - edition from 10.02.1980.

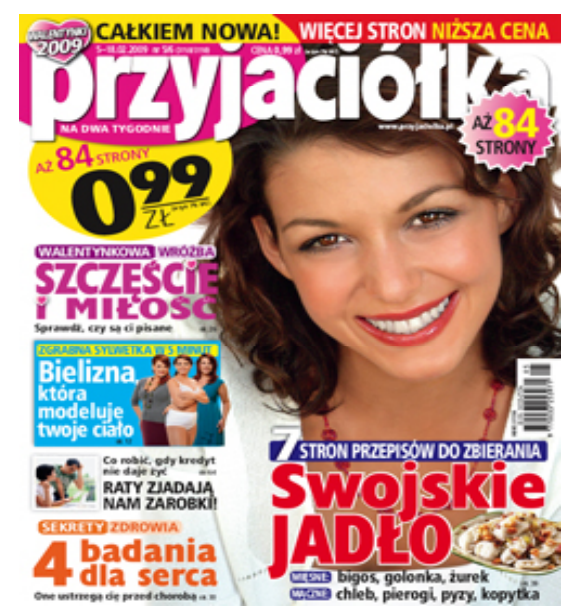

The layout of "Przyjaciótka" after 1989.

- diversity in terms of subjects, typography and political allegiances leads to publisher competitiveness like: modern layouts, advertising becomes the main source of income, special interest supplements like for example "Budownictwo" or "Motoryzacja" added to "Dziennik Łódzki".

\section{Results and Key Findings}

The analysis confirmed the political transformation caused numerous changes in the profession of press journalists. Journalists loyal to the communist 
authorities left or stopped being important. Another reason for the injection of new blood into the circle of journalists was the inability of older generation to adapt to new editorial techniques. Unlike in the past, technical skills and not political sympathies became essential (Bajka, 2000, p. 45).

The media offered quite resonable payment so young people were eager to work in editorial offices. Moreover, newly founded colleges, where students were able to major in journalism, did not lack candidates. Their graduates joined the ranks of new editorial offices of the local branches of newspapers such as "Gazeta Wyborcza" and "Super Express" or worked for commercial radio and television stations (Bajka, 2000, p. 45). The journalist market was just being created so it was easy to find a job. Inexperienced persons were needed most frequently, as experience in journalism meant that it was acquired in the former political system which was usually rejected in the "new" Poland.

At the beginning of the 1990 "the number of journalists in Poland was 11.000 . 10 years later it was $18.000-20.000$, at times the number of journalists was even 25.000. The discrepancy in the calculation is connected with disparity in qualifications. We can distinguish the following groups of journalists (Bajka, 2000, p. 42):

- full-time journalists;

- having their own business (single service journalism);

- creating its own sub local press (main income is work in other company, school or office);

- people working in public relations or media relations in other companies;

- politicians who treat themselves as journalists too;

- retirees (journalists, or former journalists connected with the association of journalists);

- journalists creating online magazines which do not have paper editions.

Wiesław Sonczyk says that this generational change after 1990 can be called "personnel revolution" (Taczkowska, 2012, p. 87). According to him "the big problem of today's media is that anyone who wants a job in the sphere can find employment. Journalists are also employees of advertising agencies, volunteers, amateurs and enthusiasts in this profession. It is a unfavourable condition for the public and also for journalists, but a convenient situation for publishers and broadcasters" (Taczkowska, 2012, p. 87). Wiesław Sonczyk notes that: "young people, who meet the minimum requirements and are fully available can often be easily manipulated" (Taczkowska, 2012, p. 87).

Nowadays, it is more difficult to become a press journalist than in the 1990s. In spite of the stability of journalistic standards, the hierarchy of most significant 
characteristics of a good journalist was the subject of substantial redefinition. In the past, social and political involvement were highly appreciated. A talented, creative and brave person was able to cope with journalism. Now these features are replaced by the powers of observation, creativeness, aptitude for making social contacts and passion to seek the truth as well as the awareness that this profession provides a ticket to the attractive media world. Today press journalists must meet substantially higher standards. A journalist is not to just provide information but also do everything to retain the readers.

It should be noted that these standards and high needs for candidates apply in the professional press editorial offices in Poland. The situation looks different in online journalism. The Internet and new technologies opened a wide spectrum of opportunities for the participation in the process of creating information not only to professional journalists but also to regular users. They can publish their texts either in online magazines or on social network websites.

The time when, regardless of qualifications, almost everybody had the chance to become a press journalist is gone. Now, journalists increasingly appreciate their place of work as: "competitors are following closely. [...] Older journalists think that they are treated in an unfair way as they are substituted by young ones, they become inconvenient and their work is not appreciated" (Pokorna-Ignatowicz, 2001, p. 28).

Working one's way up the journalist ladder requires a lot of patience and involvement. There are different types of papers and thus work in the editorial office of a daily newspaper is entirely different from work in the editorial office of a yearbook. Each of these places provides the opportunity to develop one's talent for writing and gaining professional experience. However, the best way to obtain solid journalist skills is to begin on-the-job training or attachment in the editorial office of a daily newspaper. Work there is more dynamic than in the editorial offices of periodicals. The dailies' editors-in-chief "suffer from a chronic shortage of staff" (Ziomecki, Lis, Skowroński, 2002, p. 6). As work there is in full swing it is possible to learn the ropes. First of all, journalist beginners are given substantially more tasks in the dailies than in periodicals. Initially they are assigned low-level tasks such as note taking, preparing short news, listings or even writing horoscopes and then they are gradually assigned more ambitious orders. Secondly, during the on-the-job training or attachment the young journalists are able to learn a lot from experienced staff members. What should be taken into consideration is the fact that the journalist's profession must not be treated as "a means to make a fortune". There are other occupations that allow earning considerably more and in a shorter time. At the beginning of the professional carrier, journalism does not bring many profits. Actually almost all beginners are poor people and their financial situation remains quite bad for many years. We talk about a profession where a strictly feudal system 
prevails: you are promoted with age and this requires a lot of time"(Bereś, 2007, p. 146).

However, it should be remembered that before journalist trainings begin it is necessary to know the essentials of journalistic techniques which include knowledge of the press genres and ability to make use of different sources of information. Secretaries in editorial offices note that there is no time to train the "young" for a job. That is why a candidate is required to have proper preparation and thorough factual knowledge that he/she will use in practice. These requirements are of crucial importance as numerous young journalists are criticized for frequently being unprepared for interviews, lacking basic information about their interviewees, mixing up facts and persons, asking banal, stereotype questions" (Pokorna-Ignatowicz, 2001, p.24).

Thus, it is necessary to acquire the know-how which is essential in this profession. It is also good for beginners to be acquainted with some issues, such as law, economy or culture:

"Everything is needed in this profession, each skill can be of some use but nothing specific is necessary. You must be able to make calculations in order to be a physician, you must have a driving licence to be a driver - and you do not even have to be able to write to be a journalist. That is why it is so difficult to say which skill or character trait is the decisive factor in journalism. A press journalist should certainly have passion and something else. But how to explain what this "something" is? You can be prettier, more brilliant, and more intelligent than others. On the other hand, you can be uglier and more stupid but work like a titan, insolent and a real pest. This is also a talent in journalism. That is why, journalism is an open profession where actually everybody can be admitted" (Pokorna-Ignatowicz, 2001, p.3).

However, it should be emphasized that not everybody is able to perform this social function. In spite of the numerous professional skills, a journalist must also possess some special character traits. From the very beginning, it is important for the candidate to be aware of the fact that you are a journalist for 24 hours. As Ryszard Kapuściński used to say: "We cannot just close the office at four in the afternoon and start doing something else. This is a job that fills all our lives and there is no other way to be a journalist. Or at least to be a perfect one" (Bereś, 2007, p. 145).

A staff member is expected to be permanently available, flexible, work in a rush as well as do day and night duties. Besides, a journalist must always be at the disposal of the assistant editor who can call up at night in order to give them a news assignment.

Presently, editorial offices have high demands for candidates to work in the editorial press office. We have many educational institutions training future 
journalists. Future representatives of the "fourth power" are able to study this profession on the academic (for example: Warsaw, Lodz or Cracow University), post-secondary or even vocational basis (organized by universities or editorial offices like "Dziennik Łódzki"). It is necessary to thoroughly prepare yourself in order to perform this responsible service. This preparation should be conducted in two directions. First, a candidate should acquire a wide range of general knowledge (historical, linguistic, philosophical or economic education) as well as social and political knowledge. Another requirement is certainly the knowledge of the press and journalistic techniques and genres. The modern journalist encounters both a variety of genres (article, coverage/report, interview) and techniques (press, radio, television, press agencies, Internet). Thus, a journalist is a person who deals with gathering information, editing and writing press texts (Słownik terminologii medialnej, 2006, p. 45). Press journalists can be employed by the newspaper on a full-time basis, under a contract to perform a specific task or any other contract that obliges them to produce a journalistic material.

A journalist is either a reporter collecting material or a member of an editorial office who processes, edits and elaborates information received. A permanent collaborator of the editorial office or a field correspondent also possess the status of a journalist, regardless of the fact whether they receive a fixed salary or only remuneration for lineage. What is important, a journalist can also have another job (for example work for another newspaper). However, in practice this may cause many problems as it would not allow a journalist to work for a single media organisation to maintain the necessary objectivity. This is a serious problem that particularly concerns local and sub-local papers such as, for example "Dziennik Łódzki" and "Express Ilustrowany" which are similar with regard to the editing formula although addressing different groups of readers. A student undergoing a training or traineeship is also considered to be a journalist. A newspaper library worker is also entitled to this status provided their job, apart from collecting and preparing materials, involves some creative elements.

It should be emphasised that a journalist working for a newspaper under a contract to perform a specified task, order contract as well as trainees should be provided with appropriate certificates stating that they are press journalists. In this way they become reliable and their future interviewees will have no doubts about their status.

Nowadays, editorial offices look for high demands for candidates to work in the editorial press office. Knowledge gained at university its not enough. Expectations for candidates for the profession of the press journalist reveal that they are complicated and difficult to meet. The above list should be extended with: "knowledge of the native language", as unfortunately some journalists seem to lack it. Some of them do not consider it necessary to extend their 
knowledge and improve professional qualifications. According to journalists, it is almost exclusively technical skills that constitute professionalism and learning them guarantees success in the profession (Pisarek, 1995, p. 27). Expectations towards editorial staff members are constantly growing, and that is why journalists are required to constantly increase their preparation. Last year it was easy to noticed that many editorial offices expects that their workers will also gain new skills. Press journalists occupation stopped being connected only with searching, selecting information and writing articles. Now journalists also take photos for their articles, preaper articles for the online editions of paper daily magazine. Some companies also expect that their journalists will work also to other media as radio or tv of the same owner. An example can be some regional publishers. They also opened radio or tv programs and they require that press journalists will work for them too.

The press and other media are becoming increasingly influential so professionalism and competences in journalism become a binding rule. However, it should also be said that the journalist's profession is not as safe and secure as it used to be. Employment conditions are far from being perfect. Contracts of employment are designed in such a way that a journalist may actually be made immediately redundant. There are not editorial statues or collective agreements. In many offices young journalists are treated as potential substitutes and trainee journalists are used as bogey-persons for full-time journalists.

\subsection{Discussion of Findings}

Nowadys, the meaning of journalism has changed. In other epochs the media had creating culture, propaganda and mobilization function. At present- as Wiesław Sonczyk noted-"Everything the media do build their market position and bring income to the company" (Taczkowska, 2012, p. 87). Recently a real revolution affected the journalistic profession. We found out that information is a commodity to be produced, attractively packaged and simply sold at an enormous profit. Now many titles are dominated by the publishers, who are guided only by profit. Transmission of information has secondary importance for them. Even journalists changed their attitude to their work. The research carried out in 2010 by the Polish Journalists Association (Stowarzyszenie Dziennikarzy Polskich) shows that $3 / 4$ journalists carry commands of their superiors in editorial offices. Only $11 \%$ declare directs to their conscience. $14 \%$ carry provisions of the rules and editorial statutes. Only $4 \%$ show the importance of codes of journalists' associations as signposts unions (Taczkowska, 2012, p. 92).

The political transformation after 1989 also had a big influence on reading interests of Polish people. In recent times, the interest is provoked by the colorful press (mainly gossip magazines for women). Tabloid journalism tends to emphasize topics such as sensational crime stories, astrology, gossip columns 
about the personal lives of celebrities and sports stars. Nowadays among the most widely read magazines in Poland are Gossip Weekly "Życie na gorąco" is in the second place $(15,22 \%)^{*}$, after the television magazine ("Tele Tydzień"$20,88 \%)^{* *}$. A similar situation applies to the newspapers. The most popular one is the tabloid "Fakt" (11,07\%), the second place occupies the opinion forming daily - "Gazeta Wyborcza" (7,48\%)**.

There are many reasons which led to that situation. Not only gossip is attractive to readers. The tabloid press is also identified with the worries and problems of their readers, brands what is bad, it builds its self-image as the only defender in front of the "evil world". Such fear of the "evil world" strengthens relations with dramatic and horrific events, disgusting, yet primal instinct called "voyeuristic". The tabloids tell us that their mission is to disclose, expose, and trace everything hidden from the eyes of citizens, hence the strong display of acts of crime, crimes or offenses against morality and decency. What is intentionally hidden, concealed from the people, is genuine and sincere, so the tabloids can reveal all these by focusing on them. Facts convince the recipient that they only tell the truth. And the truth is, we have a monopoly on tabloid magazines are the best mechanism for promotion.

Another way of propitiation of the readers is to create the illusion that the editors are very concerned with for example, health problems of their readers. We can say, that the narrative of tabloid magazines plays a fundamental role in society and helps in peeling the course through life for many Poles.

Polish editors also use other ways to sell their magazines. The most popular one is adding supplements. Supplements ${ }^{* * * *}$ are met with great readership interest, and are often are the only reason why a given paper is bought. Supplements are focused on particular subjects such as sports, culture, building, economy, etc. Supplements fulfil a range of functions, e.g. information, guidance, advisory, entertainment, and aesthetic. By supplement we can also understand a gadget (CD, book, cosmetic or food samples etc.). Such supplements have a great

\footnotetext{
* Numerical data come from XII-V.2016. Retrieved from http://www.wirtualnemedia.pl/ artykul/tele-tydzien-z-najwiekszym-spadkiem-czytelnictwa-wsrod-tygodnikow-duzyawans-goscia-niedzielnego-dane-tygodnikow-i-dwutygodnikow (2018, May 8).

** Numerical data come from XII-V. 2016. Retrieved from http://www.wirtualnemedia.pl/ artykul/tele-tydzien-z-najwiekszym-spadkiem-czytelnictwa-wsrod-tygodnikow-duzyawans-goscia-niedzielnego-dane-tygodnikow-i-dwutygodnikow (2018, May 8).

*** Numerical data come from XII-V. 2016. Retrieved from http://www.wirtualnemedia.pl/ artykul/tele-tydzien-z-najwiekszym-spadkiem-czytelnictwa-wsrod-tygodnikow-duzyawans-goscia-niedzielnego-dane-tygodnikow-i-dwutygodnikow (2018, May 8).

**** They can be classified into two categories. By supplement we can understand a text supplementing or complementing the main issue of the newspaper or magazine. Supplements are attached regularly or occasionally and addressed to a specific audience.
} 
influence on circulation and very often determine the commercial success of a paper (Słownik terminologii medialnej, 2006, p. 18).

It can be concluded that current readers do not just buy the magazines for their content of substance. They expect also additional attractions from their publisher, such as the above mentioned permanent or occasional text supplements and various and attractive gifts.

Publishers are in a difficult situation. They must - with each new issue of their magazine - surprise the audience and stand out from the competition to encourage their readers to chose their title and not another one.

Polish readers can also buy opinion-forming dailies and magazines. In this case, we can say that these titles create their brand. Popularity provides a carefully developed information, whose content is rich, but most of them are proven and reliable. It is most probably thanks to specialists who prepare the articles. Description of events is highly informative, it lacks exaggeration and sensationalism. The large format of such newspapers allows for information to be narrated and serious way, using a high level of language. The center of gravity is located at the national and international news from such domains as politics, economics or law. Journalists play the role of authorities and they are spokes persons of public interest.

The opinion-forming "Gazeta Wyborcza" is the most widely read daily in Poland. Its popularity depends not only on the high level of knowledge and a wealth of informative articles - but also the names of journalists who, through their work contribute to the success of this title. Other opinion-forming magazines also provoke readers' interest in Poland. They are not so popular as entertainment and gossip magazines but they have regular readers too. The press market of opinion-forming magazines is primarily divided by political criteria. Journalists are like personal advisers who help people to understand events in the country and abroad. These magazines try to build a strong position in the press market. The issue discussed must have their own identity, be original and unique looks for their own way. The most popular opinion-forming magazine in Poland is "Newsweek Polska" (6,29\%)* and its takes the 5-th position from "Tele Tydzień" - the most popular magazines in Poland.

\section{Conclusion}

The answer to the question what the media are today and what kind of role press journalists play there is still opened. Media instilled a passive and egoistic attitude to the world, which prevents us from reflection on not only personal life

* Retrieved from: http://www.wirtualnemedia.pl/artykul/tele-tydzien-z-najwiekszymspadkiem-czytelnictwa-wsrod-tygodnikow-duzy-awans-goscia-niedzielnego-dane-tygodnikow-i-dwutygodnikow (2018, May 8). 
but also on the country whose citizens we are. This mass character and satiety with the information reinforce our conviction that we do not have any influence and everything goes on without our participation. On the current situation in editorial offices journalists can only express an opinion. Nowadays for them the most important problems of journalists are that non-professionals joined this profession and that editorial offices have their own political sympathies $(44 \%)$. Also that we can observe a decline of social trust (25\%) as well as media manipulation (35\%). Pressures from own medium or outside to manipulate the content are-in the opinion of journalists-the worst practice. $1 / 5 \%$ of respondents also report about personnel abuses at work (Taczkowska, 2012, p. 93).

One of the methodologists compared journalists to "priests in ancient religions. It is true, the media have an enormous power today: they can elevate or destroy people, they can 'expel' people from society. This burdens journalists with a special responsibility. And many of them are able to face this challenge. It should be said loudly in order to oppose the vision of media as a huge mortal" (Kapuściński, 2001, p. 68).

For many editors the meaning of journalism changed. Its ceased to be only a method of inquiry and literary style used in social and cultural representation. It ceased serving the purpose of playing the role of a public service machinery in the dissemination and analysis of news and information. Journalistic integrity are ceased to be based on the principles of truth, accuracy and factual knowledge. So it needs to be highlighted that "the biggest danger of journalism of 21st century is the low level of journalism ethic. The best example of this hypothesis is journalist annual award "Hiena Roku" granted by the Polish Journalists Association (SDP). The basis for giving such "title" is violation of professional ethics, dishonesty, lack of impartiality, conduct incompatible with journalism workshop and violation of freedom of speech"*.

It is easy to observe that ideals which inspired the Polish publishers after the political transformation changed. Some editors forgot that in a democratic society, access information plays a central and the most important role in creating a system of checks and balances, and in distributing power equally between governments, businesses, individuals, and other social entities. For many of them their social mission lost its meaning. Nowadays publishing magazines started to be only a big business. Editors are ready to do everything (even to break all ethical rules) to sell their titles.

* Retrieved from: http://ssp.amu.edu.pl/wp-content/uploads/2013/06/ssp-2013-2-295-310. pdf (2017, February 6). 


\section{References:}

Bajka, Z. (2000). Reklama w mediach. In Dziennikarstwo i świat mediów (pp. 374-388). Kraków.

Bajka, Z. (2000). Dziennikarze lat dziewięćdziesiątych. In Zeszyty Prasoznawcze, vol 3-4.

Bereś, W., Burnetko, K. (2007). Kapuściński: nie ogarniam świata. Warszawa.

Chyliński, M., Russ-Mohl, S. (2008). Dziennikarstwo. Warszawa.

Filas, R. (1999). Dziesięć lat przemian mediów masowych w Polsce (1989-1990). In Zeszyty Prasoznawcze. vol. 1-2.

Fiut, I. (2000). Pisma społeczno-kulturalne w latach 1989-2000. In Zeszyty Prasoznawcze. vol. 3-4.

Kapuściński, R. (2001). Dwa światy. In. Newsweek, nr 156.

Oniszczuk, Z. (2010). Strefy wpływu kapitału niemieckiego w polskich mediach . In Prawo, etyka czy rynek? Zmiany w polskich mediach po 1989 roku. Torun.

Pokorna-Ignatowicz, K. (2010). Problemy zawodowe polskich dziennikarzy u progu XXI wieku. In Studia Medioznawcze, vol. 3.

Pisarek, W. (1995). Kwalifikacje dziennikarzy w opinii redaktorów naczelnych. In. Zeszyty Prasoznawcze. vol. 1-2.

Sobczak, J. (2000). Prawo prasowe. Warszawa.

Pisarek, W. (2006). Stownik terminologii medialnej. Kraków.

Taczkowska, J. (2012). Zawód dziennikarza w Polsce. Między misją a posłannictwem. Bydgoszcz.

Ziomecki, M., Lis, T, \& Skowroński K. (2002). ABC dziennikarstwa. Warszawa.

\section{Internet sources:}

http://www.poland.gov.pl/Development,of,a,free,press,516.html.

http://old.sdp.pl/about-us.

http://old.sdp.pl/about-us.

http://ssp.amu.edu.pl/wp-content/uploads/2013/06/ssp-2013-2-295-310.pdf

http://www.wirtualnemedia.pl/artykul/tele-tydzien-z-najwiekszym-spadkiem-czytelnictwawsrod-tygodnikow-duzy-awans-goscia-niedzielnego-dane-tygodnikow-i-dwutygodnikow. 